\title{
UNSUR EKSTRINSIK DALAM CERPEN ASRAN KARYA TRISNI SUMARDJO
}

\author{
Tengku Muhammad Sum
}

Universitas Lancang Kuning, Pekanbaru, Provinsi Riau tengkumuhammadsum@gmail.com

\begin{abstract}
ABSTRAK
This analysis proves that in Indonesian Anthology of Short Stories, especially short story written by Trisno Sumardjo entitled Asran, there are three extrinsic elements are founded. They are: social, economic, and educational elements. This analysis finds that the character of Asran is interesting to discuss because this character has different sides in his life: social, economic, and educational sides which can contribute to maturize the readers in understanding the life.
\end{abstract}

Keywords: exstrinsic, Asran

\section{PENDAHULUAN}

Cerita Pendek Indonesia semula merupakan naskah laporan pene-litian yang disusun oleh Satyagraha Hoerip dalam rangka kerja sama dengan Proyek Penelitian Bahasa dan Sastra Indonesia dan Daerah Jakarta tahun 1978/1979. Naskah ini kemudian diterbitkan jadi buku dengan judul Jakarta: Antologi 30 Cerpen Indonesia. Cerpen yang terhimpun di dalamnya merupakan karya dari penulis terkemuka Indonesia seperti Mochtar Lubis, Achdiat K. Mihardja, AA. Navis, Iwan Simatupang, NH. Dini, Umar Kayam, Mohammad Balfas, Gayus Siagian, Djamil Suherman,
Trisno Sumardjo, Muhammad Ali, Nyoman S. Pendit, Mohammad Diponegoro, Trisnoyuwono, Gerson Poyk, Suparto Brata, Wildan Yatim, N. Ratmana, S.I. Supriyanto, Fadli Rasyid, Titis Basino P.I., Umar Nur Zain, Sori Siregar, Putu Arya Tirthawirya, Danarto, Chairul Harun, Usamah, Yulius Siyaranamual, Totilawati Tjitrawasita.

Dari keseluruhan karya tersebut, penulis mengkaji cerpen Asran karya Trisno Sumardjo. Cerpen ini mengkisahkan kehidupan sosok Asran, seorang pelukis muda yang gaya hidupnya berbeda dengan orang kebanyakan. Unsur yang dikaji 
adalah faktor luar atau unsur eksintrik karya. Unsur ekstrinsik merupakan sarana bagi masyarakat untuk mengetahui keadaan luar dari dalam cerita seorang pengarang. Menurut Wellek dan Warren dalam Nurgiyantoro (2009: 23), unsur ekstrinsik adalah keadaan subjektivitas pengarang tentang sikap, kaya-kinan serta pandangan hidup yang menjadi latar belakang terlahirnya sebuah karya fiksi, bisa dikatakan kalau unsur biografi pengarang dapat menentukan ciri karya yang dihasilkan. Unsur ekstrinsik dapat memberikan gambaran luar, yang dapat menghasilkan produk karya yang menggiurkan dengan olahan perasaan/subkjektivitas seorang pengarang.

\section{SINOPSIS}

Cerita pendek berjudul "Asran" menceritakan tentang seorang pemuda bernama Asran. Asran memiliki bakat seni lukis yang cukup luar biasa. Ia memiliki ibu yang sudah tua. Ia bercita- cita memberangkatkan ibunya pergi haji sebelum sang ibu meninggal. Demi cita-citanya itu, ia pun berusaha dengan segala upaya agar dapat mengumpulkan uang sebanyak mungkin.

Namun, kehidupan Asran san-gat memprihatinkan karena jangankan rumah, pakaian saja dia saja dia hanya punya dua pasang dan itu pun sudah kumuh. Setiap orang yang melihat Asran akan menaruh rasa kasihan padanya. Keadaan Asran jauh dari kata layak. Pada mulanya, Asran adalah mahasiswa Akademi Seni Rupa, namun setelah dua tahun mengikuti pelajaran, Asran keluar dari lembaga pendidikan itu dan mulai hidup mengembara. Tabiatnya yang gelisah membuat dia tak bisa menetap lama di suatu tempat. Ia mencoba tinggal di Bandung dan juga Bali karena rasa ingin tahunya akan kedua kota tersebut yang dikenal sebagai wilayah tersubur bagi perkembangan seni rupa. Dalam perkelanaannya dari kota-kota itu, ia mampu membuat puluhan bahkan ratusan sketsa. Hal yang menarik dari Asran adalah kemampuan dan kegairahanya dalam berkarya dengan segala keterbatasan. Cat, kuas dan kanvas adalah alat utama yang dibutuhkan pelukis. Karena kondisi ekonomi Asran yang penuh keterbatasan sudah barang tentu ia tidak mampu membeli peralatan tersebut. Akan tetapi, keterbatasan itu pulalah yang menyebabkan daya kreatif Asran begitu tinggi. Ia tidak lagi terikat dengan pakem. Tidak ada kanvas, ia menggunakan kertas sebagai wadah untuk meluahkan 
ekspresi dan segala kegelisahannya. Kertas apapun tak ia pedulikan. Kertas tik, kertas gambar, kertas hijau atau kuning, bahkan sobekan kertas yang dibuang pun ia gunakan. Yang penting, selagi ada ruang ko-song untuk mencoret maka ia akan memanfaatkannya. Selagi ada pena dan tinta maka Asran tak akan ber-henti menggores.

Hubungan Asran dan ibunya berjalan baik walau karena gaya hidupnya yang bohemian mem-buat Asran jarang pulang menemui ibunya di Jakarta. Namun, diakhir cerita rupanya pengembaraan Asran selesai juga dan ke tangan ibunya juga nasibnya bergantung. Selain mengembara ke Bandung dan Bali, Asran juga menuju Yogyakarta. Disana ia menikah dengan seorang perempuan yang usianya enam tahun lebih tua darinya. Akan tetapi rumah tangganya tidak bertahan lama karena masalah internal keluarga. Ibu Asran juga kurang menyukai istri anaknya itu. Setelah bercerai, Asran melanjutkan lagi pengem-baraannya. Ia pindah dari kota ke kota. Satu hal lagi yang menarik dari Asran selain daya kreatifnya yang tinggi adalah kemampuan dia untuk beradaptasi dan bersosialisasi dengan baik, sehingga ia memiliki banyak teman.
Di setiap kota yang ia kunjungi, ia memiliki teman yang siap membantunya dalam kesulitan, baik kesulitan materil maupun tem-pat tinggal. Namun, gaya hidup As-ran yang terlalu mengikuti perasaan tanpa target yang jelas membuat dia terkatung-katung. Cita-citanya untuk menghajikan ibunya juga gagal. Akhirnya, ibu Asran mencarikan jodoh untuk putranya itu. Asran tidak menolak. Hidup Asran setelah itu diatur oleh ibu dan istrinya.

\section{PEMBAHASAN}

Dalam cerpen Asran, terdapat tiga unsur ekstrinsik, yaitu unsur sosial, unsur ekonomi, unsur pendidikan.

1. Unsur Sosial

Unsur sosial merupakan suatu tindakan perorangan terhadap ruang lingkup keluarga dan masyarakat. Adapun unsur sosial yang terdapat dalam cerpen Asran bisa dilihat dari kutipan di bawah ini:

"Dan betul: pemuda itu pulang dengan gembira, singgah di Jakarta untuk menengok ibunya. Tapi orang tuanya yang satu-satunya itu mengancam dia mengenai perkawinan-nya."( hal. 46).

Dari kutipan di atas jelas As- 
ran merupakan sosok yang memiliki jiwa sosial terhadap keluarganya. Terutama ibunya. Tidak hanya itu Asran pun suka berpindah dari kota ke kota karena jiwa sosialnya yang tinggi. Dari kutipan yang ada di bawah ini jelas terlihat bagaimana ia hidup nomaden.

"Sekali lagi, pemuda kita kali ini kelaparan, ketika tiba di Malang. Dari pelukis lain ia mendengar bahwa telah pindah ke kota itu seorang dokter Jerman kelahiran Belanda, yang dulu pernah beli sketsa-sketsanya, ketika ia mengadakan salah-satu kunjungannya ke Surabaya. Rekan tadi mengan-tarnya untuk mencari alamat dokter-kolektor tersebut." (hal. 47).

Jiwa seni Asran mengantarkannya ke beberapa kota sesuai dengan kutipan di atas. Ia pernah mengunjungi Malang dan Surabaya. Asran merupakan individu yang tidak bisa tinggal lama di suatu kota atau daerah. Ia suka berpindah tempat. Hal itu terlihat dari kutipan yang ada di bawah ini:

"Dan tiga hari kemudian ia telah menyelesaikan tugasnya itu dengan hasil yang memuaskan pemesannya. Dan dengan itu ia berpamitan pada tuan rumahnya yang baik hati itu.

"Mengapa tergesa pulang?" tanya

dokter P.

"Isteri saya ada di Yogya."

"Kau beristeri, As? " tanya lawan-cakapnya heran dan kemudian bertanya lagi, "Kenapa kau tak bilang-bilang bahwa kau sudah beristeri?"

"Tuan tak pernah bertanya," jawabnya.

"Iya, ya saya memang tidak bertanya. Tapi sekarang saya tanya, apa kau punya anak?"

"Ada, dua."

Dokter geleng -geleng kepala, "Nah, Asran," ujarnya sejurus kemudian "Ini uang untukmu buat bayar dua lukisan. Dan ini ada beberapa potong pakaian." (hal. 52).

Kutipan di atas cukup memberi bukti bahwa Asran, walaupun ia seorang pribadi yang terkesan individualis dengan pilihan gaya hidup yang berbeda dengan orang kebanyakan, namun sebenarnya dia memiliki kesadaran sosial yang tinggi. Ia memiliki rasa sayang dan tanggung jawab pada istrinya di 
Yogya dan juga ibunya di Jakarta. Asran sebenarnya seorang yang cinta keluarga.

Namun, rasa cinta terhadap keluarga yang dimiliki Asran, tidak mampu pula mengalahkan satu sisi pribadi Asran yang selalu gelisah. Rasa gelisah inilah yang membuat Asran menjalani hidup bohemiannya. Ia menjadi seorang pengelana yang berpindah-pindah dari satu kota ke kota yang lain. Hal ini bisa dilihat dari kutipan berikut :

"Asran telah pulang ke Yogya dan kemudian ke Jakarta, di mana saat itu orang sedang ramai-ramainya menyelenggarakan Asian Games dan sesudah itu Genefo. Ia membuat puluhan sketsa untuk dokumentasi, tapi panita menganggap bayarannya sudah cukup jika memberinya uang-saku dan uang -makan selama bertugas serta kesempatan baginya melihat semua tontonan dengan cumacuma."(hal. 52)

Tentang hubungan dengan sesama teman, Asran cukup memiliki loyalitas. Ia akan bersedia membantu temannya yang membutuhkan pertolongan. Hal itu terbukti dari kutipan yang ada di bawah ini:

“As, kau mesti berpakaian yang bersih, "katanya.

"itu kudengar dua kali, hari ini, “ sahut lawan cakapnya.

"Kuberi, nanti. Kalau kau tak suka pakaian itu, boleh kau buang, kemudian. Kalau suka, bawa saja. Tapi sebelumnya aku akan minta bantuanmu. Aku cinta seorang gadis. Sekarang aku mau nulis surat, antarkan surat itu kepadanya. Kupikir tak ada seorang yang lebih tepat darimu, As. Kuharap kau mau, menolong seorang kawan."

"Boleh", jawab Asran. "Dalam surat itu kuminta ia datang ke suatu tempat. Kalau dia mau, lekas beri tahu aku ya , As."

"Baik," kata Asran.” (hal.54)

Jiwa Asran yang sering didekati rasa gelisah dan gundah membuat-nya menjadi makhluk nomaden. Ia mengembara dari satu tempat ke tempat lainnya. Hal itu terlihat dari kutipan yang ada di bawah ini:

"Asran merasa kegerahan. Ia gelisah. Ia merasa kehilangan sesuatu. Lalu ia pergi ke pulau Bali. Di sana dibuatnya banyak sekali sketsa dan lukisan tentang tamasya, tentang orang-orang Pulau Dewata itu, tentang kampung 
dan babi-babi piaraan penduduk dusun." (hal. 55)

Pengembaraan yang terli-hat seperti tanpa akhir, membuat Asran tidak memiliki kehidupan yang tenang dan hidupnya tersebut tanpa arah dan tujuan. Dengan menjalani kehidupan seperi itu, Asran tidak melakukan apapun untuk memperbaiki kehidupannya yang gelisah dan tidak menentu. Bagaimana mungkin dia dapat mencapai niatnya untuk membawa ibunya pergi haji bila ia belum dapat memperbaiki kehidupannya sendiri. Keadaan ini berlangsung selama bertahun-tahun dan ia menjalani kehidupan seperti ini sampai ibunya bertambah tua dan waktu berlalu dengan sia-sia.

\section{Unsur Ekonomi}

Unsur ekonomi yang terdapat dalam cerpen Asran cukup banyak karena cerita ataupun kisahnya menggambarkan sosok dengan kehidupan ekonomi yang sulit. Asran adalah seniman kere dengan pola pikir yang sulit dipahami orang kebanyakan. Ia menjalani hidupnya dengan menuruti kata hati. Jiwanya yang haus akan 'sesuatu' membuat dia tidak terlalu peduli dengan capaian-capaian duniawi, bahkan termasuk soal pakaian yang dipakai pun juga tempat tinggal. Namun, walau demikian bukan berarti Asran anti uang sama sekali. Asran sebenarnya seorang yang gigih dan giat bekerja serta punya niat yang besar yakni menghajikan orang tuanya. Hanya saja, Asran tidak terlalu memikirkan jumlah yang ia peroleh dari hasil kerjanya. Berapa pun upah yang diberi akan ia terima. Yang penting baginya ia tetap bisa membuat sketsa dan bisa meluahkan energi kreatifnya.

"Asran seorang pelukis muda, mengejar sesuatu dengan gigih di samping keseniannya. Ibu-nya sudah tua. Sebelum ibu-nya meninggal, Asran memberi tugas utama pada diri-sendiri untuk berusaha agar orang tua itu bisa naik haji. Inilah yang membuat pikirannya padat un-tuk mencari duit dalam keadaan yang bagaimana pun." (hal. 44).

Kehidupan ekonomi Asran yang kalang kabut tidak membuat ia menyerah. Sesulit apa pun ia tetap melukis, walaupun ia tak mampu untuk membeli alat lukis. Hal itu dapat dibuktikan pada kutipan yang ada di bawah ini :

"Ia jarang melukis dengan cat sebab tak kuat membelinya. 
Tapi tak apa. Tinta dan pena merupakan senjata yang memberinya cukup kepuasan." (hal. 45).

Walau Asran sosok yang gigih dalam mencari uang, ia tetap saja sering berada dalam kesulitan. Ia acapkali kehabisan uang. Tapi, menariknya, Asran tidak pernah menyerah dan tetap menjalani hidupnya dengan penuh gairah. Dan memang ada-ada saja jalan rezeki baginya disaat ia betul-betul berada di titik nol.

"Asran kehabisan uang lagi, ketika ia sembuh. Untunglah ada pesanan dari Bandung untuk membuat hiasan keramik. Pot bunga, vas, dan lainnya sedang mempunyai pasaran bagus, waktu itu. Perusahaan keramik mendapatkan untung besar. Tapi pemimpinnya sudah mengenal Asran sejak dulu, ia tau pelukis itu tak akan membantah jika menerima bayaran yang hanya sekedarnya sekali-pun." (hal. 46).

Kesulitan ekonomi Asran sampai pada hal paling dasar. Untuk makan pun ia mesti menjual pakaian yang melekat di badan. Tak jarang juga ia mesti berhutang pada temannya.
"Selesai mengisi perut, Asran berbisik ke pada kawannya, "Eh, kau ada duit?"

Yang ditegur terkejut, "He aku tak punya apa-apa. Kan kau, yang ngajak aku ke sini tadi?". "Tak apalah."

Asran tetap tenang. Ia membuka kancing-kancing bajunya lalu dicopotnya baju itu. Temannya yang mula-mula heran mulai paham.

"As, jangan bikin malu aku dong! Aku sudah lama kenal tukang warung ini. Dia langgananku." (hal. 47).

Tapi, di tengah kesulitan mendasar tersebut, Asran tetap saja meneruskan kebiasaannya untuk mengembara yang sudah pasti memerlukan ongkos perjalanan.

"Aku tak punya uang, buat ongkos perjalanan," kata temannya. "Aku ada."

"Buat makan nanti bagaimana?"

"Beres, jangan kuatir!" "Sekali lagi Asran makan ber-sama orang lain di kedai nasi dan sekali lagi ia mesti menyelesaikan masalah pembayarannya.

"Tunggu di sini," ujarnya sambil berdiri. 
"Kau ke mana?" tanya kawannya, heran.

"Ambil uang."

"Ambil uang? Di mana? Kau kenal orang, di sini?" "Dokter itu, kan."

"Wah, belum tentu dia mau kasih!"

"Dia akan kasih." (hal.47).

Dengan berjualan sket-salah, Asran bertahan hidup. Walau sering kelaparan dan tidak punya tempat tinggal, Asran dikelilingi orangorang baik. Orang-orang itu sebenarnya merasa heran dengan pilihan hidup Asran dan berusaha memberikan nasehat, tapi Asran tetap kukuh dengan apa yang ia yakini. Ada-ada saja pembelaannya terhadap kebiasaan hidupnya itu.

"Dengan menjual beberapa sketsanya lagi, Asran mendapat pesangon yang lumayan buat pergi ke Bandung. Dia kunjungi seorang pedagang dan minta supaya boleh menginap di rumahnya. Tuan rumah tak bermaksud menolak, tapi ia suka bersenda-gurau dengan cara tersendiri yang kurang sedap didengar,

"Kau mesti berpakaian lebih patut dulu, sebelum menginap di rumah orang As. Mengapa kau tak suka pakaian yang bersih?"

"Jiwa saya bersih," jawab yang ditegur.

"Tapi itu tak kelihatan. Orang hanya melihat apa yang dapat mereka lihat, dengan mata." "Saya dapat melihat apa yang tak dapat dilihat orang lain," sahut Asran.

"Kau mau menginap disini? Boleh. Tengok: Perkarangan saya luas. Kau boleh tidur di luar. Jangan dekat rumah ya, sana ..."

Asran tak berkata apa-apa. Ia bangkit dan masuk perkarangan. Tapi ia terus melintas ke jalanan dan pergi. Tersuruksuruk, dengan batin yang lesu, sampailah ia di rumah seorang yang dikenalnya yang masih menuntut pelajaran di Akademi.“" (hal. 53).

"Sekali lagi, pemuda kita kali ini kelaparan, ketika tiba di Malang. Dari pelukis lain ia mendengar bahwa telah pindah ke kota itu seorang dokter jerman kelahiran Belanda, yang dulu pernah beli sketsa-sketsanya, ketika ketika ia mengadakan salah-satu kunjungannya ke Surabaya. Rekan tadi mengantarnya untuk men- 
cari alamat dokter-kolektor

tersebut." (hal. 47)

Dari berbagai kutipan di atas, unsur ekonomi yang menarik sebagai bagian dari hal ekstrinsik cerpen Asran adalah perjuangan sosok pribadi Asran untuk bertahan pada pola pikir a-materi di tengah masyarakat yang berkubang dalam tatanan hidup baru usungan modernisme: materialisme. Walau pun di akhir cerita rupanya Asran 'jinak' juga di tangan ibu dan istri barunya.

\section{Unsur Pendidikan}

Pendidikan merupakan hal mendasar yang dibutuhkan seseorang untuk meningkatkan taraf hidupnya. Setidaknya itulah yang diyakini masyarakat umum sekarang. Pandangan umum bahwa pendidikan berhubungan dengan ijazah. Ijazah akan berkaitan dengan kemudahan mendapat pekerjaan. Namun, Asran memiliki pemaknaan sendiri terhadap pendidikan. Baginya, pendidikan tidak semata berhubungan dengan ijazah. Pendidikan baginya berkaitan dengan sebuah hakikat 'pemanusiaan' manusia. Sebagaimana pilihan hidupnya yang melawan arus begitu juga pemaknaannya terhadap pendidikan. Capaian pendidikan tidak hanya yang berhubungan dengan materi semata tapi yang utama adalah perkembangan pribadi manusia sebagai sosok pembelajar. Oleh karena itu, walaupun Asran pernah kuliah di Akademi Seni Rupa, ia memilih untuk keluar.

"Setelah dua tahun mengi-kuti pelajaran di suatu Akademi Seni Rupa, Asran ke luar dari lembaga pendidikan itu dan memulai hidup mengembara. Tabiatnya yang gelisah tak membiarkan dia menetap lamalama di suatu tempat." (hal.44).

Yang lebih penting bagi seorang Asran adalah ilmu yang dimiliki yang kemudian diasah terus dengan praktek. Ijazah baginya hanyalah legalitas dan ia tidak terlalu ambil peduli.

"Asran, kau belajar di mana?" Tanya dokter P.

"Akademi. Tapi tak tamat." Dokter lalu mengambil bukubuku yang memuat kumpu-lan reproduksi lukisan, karya tokohtokoh besar Eropa. "Kau bisa terka, karya siapa ini?"

Tanpa ragu-ragu yang ditanya itu menjawab, "Michael Angelo!" itu karyanya dalam gereja di Sistina, di Ruma." "jadi kau tahu juga ini?" 
"Matisse, ketika masih muda."

"Betul! Dan ... ini?"

"Van Gogh. Waktu dia berdiam

di Arles, Prancis Selatan."

Pengujinya terdiam. Tak me-

nyangka akan mendapat jawa-

ban-jawaban yang setegas itu.

"kau boleh tinggal di sini," katanya. "Kau boleh melukis di kamar belakang." (hal.49).

\section{SIMPULAN}

Dalam cerita pendek yang berjudul "Asran" terdapat unsur ekstrinsik, seperti unsur sosial, unsur ekonomi dan unsur pendidikan. Unsur sosial yang terkandung adalah gambaran seorang individu bohemian namun tetap memiliki rasa tanggung jawab pada keluarga (ibu dan istri). Selain itu, walaupun terkesan memikirkan diri sendiri, Asran adalah sosok yang loyal, mudah beradaptasi dan bersosialisasi. Oleh karenanya ia memiliki banyak teman yang setia yang senantiasa bersedia menolong. Adapun unsur ekonomi adalah pilihan hidup Asran yang anti mainstream. Disaat masyarakat pada zamannya secara umum memiliki capaian ekonomi yang jelas dan terukur dengan kepemilikan materi sebagai standar ukurannya, Asran sama sekali tidak memiliki standar itu. Baginya yang terpenting adalah pemuasan hasrat 'pengembaraannya' demi sebuah gairah hidup yang sangat abstrak untuk dijelaskan. Karenanya tokoh Asran sering kali kelaparan dan pakaiannya pun begitu kumuh. Namun, walau demikian Asran bukanlah seorang pemalas. Ia seorang yang gigih dan tekun bekerja serta dapat dipercaya. Hanya saja, Asran memang memiliki standar capaian sendiri yang berbeda dengan orang banyak. Adapun unsur pendidikan dari cerpen Asran ini adalah tentang pemaknaan terhadap hakikat pendidikan. Jika secara umum pendidikan dikaitkan dengan ijazah dan pekerjaan, maka Asran memandang pendidikan sebagai jalan untuk memanusiakan manusia. Lagi-lagi adalah sebuah konsep abstrak yang sulit dijabarkan. Bagi Asran, ilmu dan praktek lebih penting dari pada sekedar selembar ijazah. Akhirnya, menurut penulis, cerpen ini memberi warna baru bagi masyarakat dalam memahami persoalan kehidupan yang terjadi di lingkungan mereka. Setiap persoalan di dalam cerita pendek ini diselesaikan oleh sang tokoh dengan cara yang unik.

\section{DAFTAR PUSTAKA}

Ali, Muhammad. 1986. Sastra dan Manusia. Surabaya : PT. Bina 
Indra Karya Surabaya.

Bobsusanto. 2015. 7 Pengertian

Cerpen Menurut Para Ahli

Dan Ciri Cirinya. http://www. spengetahuan.com/2015/10/7pengertian-cerpen-menurutpara-ahli-dan-ciri-cirinya.

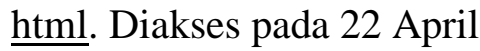
2018 Pukul 15:14.

Dua Puluh Sastrawan Bicara. Dua Puluh Sastrawan Bicara. Jakar-ta : Dewan Kesenian Jakarta. 1984.

Heryanto, Ariel. 1985.Perdebatan Sastra Konstekstual. Jakarta : CV. Rajawali.

Junus, Umar. 1985. Dari Peristiwa
Ke Imajinasi. Jakarta : PT. Gramedia.

Lahiya. 2016. Cerpen: Unsur Intrinsik, Unsur Ekstrinsik, Pengertian, Dan Struktur. http://www.lahiya.com/ cerpen-unsur-intrinsikunsur-ekstrinsik-pengertiandan-struktur/. Diakses pada 22 April 2018 Pukul 14:59.

Nurgiyantoro, Burhan. 2009. Teori Pengkajian Fiksi. Yogyakarta: Gajah Mada University Press. Suryadi AG, Linus. 1989. Di Balik Sejumlah Nama. Yogyakarta: University Press. 